\title{
SADAFCO: The Food Basket of GCC
}

\author{
Dr. Zaid Ahmad Ansari \\ Professor of Marketing, College of Business and Economics, Qassim University, Buraidah, Saudi Arabia \\ *Correspondence: Dr. Zaid Ahmad Ansari, Drzaidansari@gmail.com
}

\begin{abstract}
Saudia Dairy and Foodstuff Company as popularly known the SADAFCO [1], is one of the leading companies in the Gulf region and professionally managed supply chain management to ensure food for all. In terms of quality assurance, it obtained International Standard Organisation's (ISO22000:2005) certificate and enjoyed a competitive advantage in diary industry and milk based products in serving approximately 32000 customers across the GCC region. It also enjoyed a network of distributors without any forward or backward integration strategy to cater the need of the vast markets it serves in UAE, Kuwait, and Bahrain in GCC including Jordon.
\end{abstract}

SADAFCO has about 45 years of rich experience in the industry and started all commercial activities ranging from manufacturing, storage, distribution to other logistics management after being established in 1976. SADAFCO is a Saudi brand name to be reckoned with that offered kitchen and dining table items and a wider range of products across several product lines including Milk, Tomato Paste, Ketchup, Snacks, Ice Cream, Cheese, Instant Milk Powder, Creamy Products, Fruit Nectars, Butter and French Fries to mention a few. Henceforth SADAFCO is a leading and world-class company in the GCC region. The company has good financial position over the given period of time. The challenges brought forward by the Covid-19 is not an exception to this global economic challenge has yet to be seen depending upon the financial performance of year 2020 .

Historically this Saudi dairy and Foodstuff Company expanded its capacity of manufacturing and distribution after being merged with two other dairy companies and ownership was transferred to make it as holding company to be listed in home and GCC in 2005. Eventually it was listed on the Saudi Arabian stock exchange TADAWUL [2] while majority shareholding with the new entity goes to Qurain Petrochemicals Industries (QPIC). Today's SADAFCO is a brand power and well sought after share in the securities market of the Kingdom.

Keywords: SADAFCO, Gulf region, Food and dairy

\section{ARTICLE INFORMATION}

Author(s): Dr. Zaid Ahmad Ansari

Received: 13 Dec, 2020; Accepted: 15 Jan, 2020; Published: ; e-ISSN: 2347-4696;

Paper Id: BMN-IJBMR-2021-2;

Citation: doi.org/10.37391/IJBMR.090102

Webpage-link: https://ijbmr.forexjournal.co.in/archive/volume-9/ijbmr-090102.html

\section{BACKGROUND}

SADAFCO is a leading brand in supply chain management in the Kingdom of Saudi Arabia and a world-class company. Brand sells and beside UHT milk, Saudia Tomato paste and ice cream many other product lines are also enjoying the brand leader position of local and regional markets. UHT (Long Life) Milk marketed in Saudi Arabia, with the Saudia brand capturing more than half of the Long-Life Milk market and almost a third of total drinking milk Among the established brands are Crispy and Baboo's names also included Cheese, Instant Milk Powder, Fruit Nectars, Butter and French Fries in its list of popular names.

Furthermore the company's accesses to other GCC nations especially the United Arab Emirates are carried out through external distributors and agents to give it a unique and fast reach compared to other competitors to enjoy fast mover benefits. Company's manufacturing facilities are located in the east and west regions - Dammam and Jeddah respectively. These manufacturing facilities are accredited for quality assurance through ISO 22000:2005 certificate for assuring customer patronage and confidence in its wide range of product categories.

The management by objectives (MBO) is guiding principle of the company. Just like most companies and organizations in Saudi Arabia, compliance to the kingdom laws and regulations that are driven from Islamic cultural values and laws (Sharia). Below are the four core management values of SADAFCO, which are all aligned and derived from Islamic values. These are driving forces behind the success of the company-Inspire, Engage, Create and Deliver.

Inspire: By working to develop and plan for the solutions, a value is driven from the Kingdom's cultural value for planning, which is a process for estimating, scheduling, risk planning and other concepts to be prepared for future.

Engage: It is the process of cooperating, collaborating, organizing, and having a formal as well as informal team work in place.

Create: The process of making and building, based on the guides and strategic roadmaps set before, finding and recharging the motivation of the people or the employees 
doing the work.

Deliver: It is the process of delegating over the work, deliver it as per planned, and it includes the most important components, which are the audits and review to compare what is done accordingly to what was planned. The audit process is a subcategory of a broader value of management control.

This case study is therefore has the above objectives and guided by these values and its impact on financial performance of the company as given in the tables.

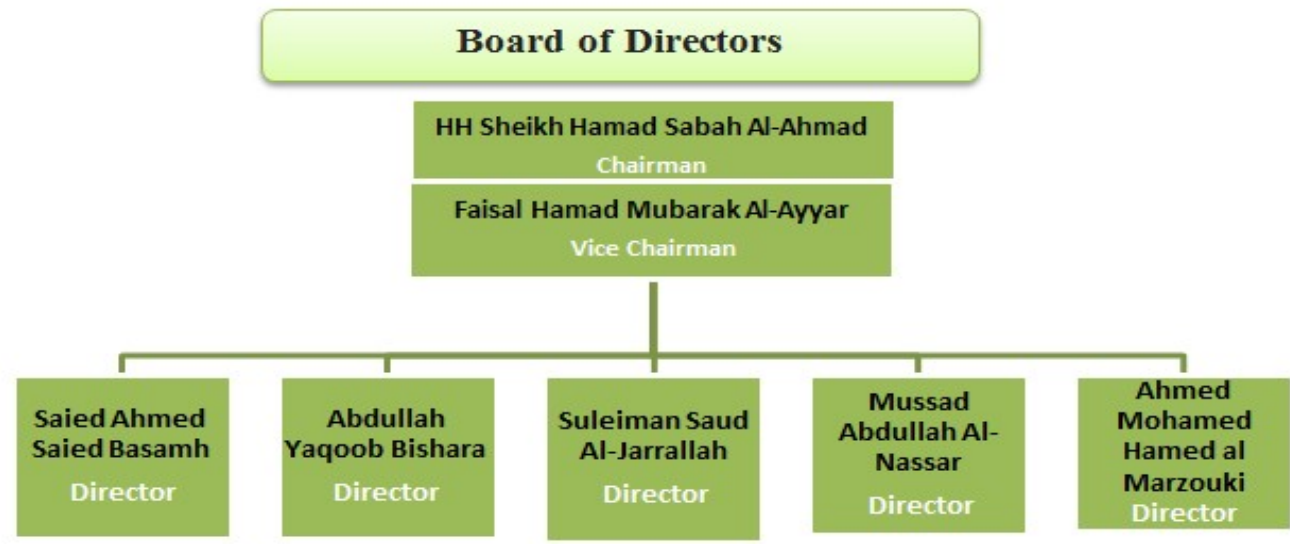

Figure 1: Organizational structure of SADAFCO

After the well planned merger exercises carried out by the SADAFCO during 2025 whereby the Qurain Petrochemicals Industries (QPIC) is considered the largest shareholder of SADAFCO as represented in its organizational restructure (figure 1), expansion took place and the company's factories presently produced 40 million units annually. Logistically SADAFCO's trucks travel approximately 18 million kilometers a year delivering goods to 23 depots to serve about 32000 customers across the Kingdom and the neighboring GCC member nations. Presently there are 19 depots within the Saudi Arabia and one each in Bahrain, Qatar, Kuwait and Jordon that provided SADAFCO a wide ranging international networking of sales and high level of market penetration rate.

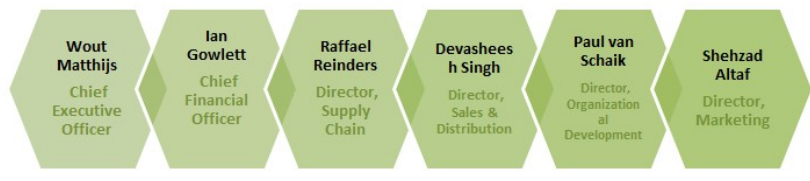

Figure 2: Management Chart of SADAFCO

Performance matters a lot. The management effectiveness can be gauged with the financial indicators as follows in the next table. This proves the efficiency as positions held by the members of team at the different professional level of the management chart (figure 2) as depicted above are measured in terms of company's financial health.

As the tables 1, 2 explains the return on investment by enhanced equity of share holders' for the last four years during 2016-2019 as SAR 1,092,219 in 2016, SAR 1,260,663 in 2017, SAR 1,321,150 in 2018 and SAR 1,338,445 in 2019 respectively.
Similarly the sales turnover of the company has caught up in 2019 to SAR 1,812,960 despite a dip of SAR 1,692,683 during 2018 after excellent performance previously SAR 1,857,739 and SAR 1,982,764 during years 2017 and 2016 respectively.

\begin{tabular}{|c|c|c|c|c|}
\hline $\begin{array}{l}\text { BALANCE } \\
\text { SHEET }\end{array}$ & $\begin{array}{c}\text { 2019-03- } \\
31\end{array}$ & $\begin{array}{c}\text { 2018-03- } \\
31\end{array}$ & $\begin{array}{l}2017- \\
03-31\end{array}$ & $\begin{array}{l}2016- \\
03-31\end{array}$ \\
\hline $\begin{array}{l}\text { Current } \\
\text { Assets }\end{array}$ & 817,687 & 751,946 & 722,352 & $\begin{array}{c}431,93 \\
8\end{array}$ \\
\hline Inventory & 277,417 & 347,901 & 321,429 & $\begin{array}{c}381,12 \\
0\end{array}$ \\
\hline Investments & 4,904 & 243 & 243 & 243 \\
\hline Fixed Assets & 787,021 & 663,087 & 598,004 & $\begin{array}{c}577,20 \\
3\end{array}$ \\
\hline Other Assets & 28,713 & - & - & - \\
\hline Total Assets & $1,915,742$ & $1,763,177$ & $\begin{array}{c}1,642,02 \\
8\end{array}$ & $\begin{array}{c}1,390, \\
504\end{array}$ \\
\hline $\begin{array}{l}\text { Current } \\
\text { Liabilities }\end{array}$ & 420,374 & 329,133 & 268,724 & $\begin{array}{c}196,49 \\
8\end{array}$ \\
\hline $\begin{array}{l}\text { Non-Current } \\
\text { Liabilities }\end{array}$ & 137,509 & 112,672 & 111,072 & $\begin{array}{c}100,42 \\
2\end{array}$ \\
\hline $\begin{array}{l}\text { Other } \\
\text { Liabilities }\end{array}$ & - & - & - & - \\
\hline $\begin{array}{l}\text { Shareholders } \\
\text { ' Equity }\end{array}$ & $1,338,445$ & $1,321,150$ & $\begin{array}{c}1,260,66 \\
3\end{array}$ & $\begin{array}{c}1,092, \\
219\end{array}$ \\
\hline $\begin{array}{l}\text { Total } \\
\text { Liabilities } \\
\text { and } \\
\text { Shareholder } \\
\text { Equity }\end{array}$ & $1,915,742$ & $1,763,177$ & $\begin{array}{c}1,642,02 \\
8\end{array}$ & $\begin{array}{c}1,390 \\
504\end{array}$ \\
\hline
\end{tabular}




\begin{tabular}{|l|c|c|c|c|}
\hline $\begin{array}{l}\text { Minority } \\
\text { Interests }\end{array}$ & 19,414 & 222 & 1,569 & - \\
\hline $\begin{array}{l}\text { All figures } \\
\text { are in }\end{array}$ & $\begin{array}{c}\text { Thousand } \\
\mathrm{s}\end{array}$ & $\begin{array}{c}\text { Thousand } \\
\mathrm{s}\end{array}$ & $\begin{array}{c}\text { Thousan } \\
\mathrm{ds}\end{array}$ & $\begin{array}{c}\text { Thousa } \\
\text { nds }\end{array}$ \\
\hline Currency & SAR & SAR & SAR & SAR \\
\hline
\end{tabular}

Table 1: Financial Performance of SADAFCO (Balance Sheet)

\begin{tabular}{|c|c|c|c|c|}
\hline $\begin{array}{l}\text { STATEMEN } \\
\text { T OF } \\
\text { INCOME }\end{array}$ & $\begin{array}{c}\text { 2019-03- } \\
31\end{array}$ & $\begin{array}{c}\text { 2018-03- } \\
31\end{array}$ & $\begin{array}{c}\text { 2017-03- } \\
31\end{array}$ & $\begin{array}{l}2016- \\
03-31\end{array}$ \\
\hline Sales & $1,812,960$ & $\begin{array}{c}1,692,68 \\
3\end{array}$ & $\begin{array}{c}1,857,73 \\
9\end{array}$ & $\begin{array}{c}1,982,7 \\
64\end{array}$ \\
\hline Sales Cost & $1,189,586$ & $\begin{array}{c}1,020,49 \\
4\end{array}$ & $\begin{array}{c}1,047,56 \\
4\end{array}$ & $\begin{array}{c}1,222,6 \\
09\end{array}$ \\
\hline Total Income & 623,374 & 672,189 & 810,175 & 760,155 \\
\hline $\begin{array}{l}\text { Other } \\
\text { Revenues }\end{array}$ & 11,368 & 8,214 & 4,996 & 423 \\
\hline $\begin{array}{l}\text { Total } \\
\text { Revenues }\end{array}$ & 634,742 & 680,403 & 815,171 & 760,578 \\
\hline $\begin{array}{l}\text { Admin and } \\
\text { Marketing } \\
\text { Expenses }\end{array}$ & 333,001 & 334,201 & 423,529 & 402,324 \\
\hline Depreciation & 68,391 & 65,403 & 75,847 & 82,173 \\
\hline $\begin{array}{l}\text { Other } \\
\text { Expenses }\end{array}$ & - & - & $-6,668$ & -80 \\
\hline $\begin{array}{l}\text { Total } \\
\text { Expenses }\end{array}$ & 401,392 & 399,604 & 492,708 & 484,417 \\
\hline $\begin{array}{l}\text { Net Income } \\
\text { Before Zakat }\end{array}$ & 233,350 & 280,799 & 322,463 & 276,161 \\
\hline Zakat & 17,240 & 20,577 & 20,690 & 15,333 \\
\hline Net Income & 216,110 & 260,222 & 301,773 & 260,828 \\
\hline $\begin{array}{l}\text { Balance First } \\
\text { Period }\end{array}$ & 627,042 & 592,710 & 454,163 & 335,121 \\
\hline Reserves & 21,839 & 26,088 & 30,101 & 26,021 \\
\hline $\begin{array}{l}\text { Cash } \\
\text { Dividends }\end{array}$ & 130,000 & 195,000 & 130,000 & 113,750 \\
\hline $\begin{array}{l}\text { Other } \\
\text { Distributions }\end{array}$ & 18,046 & 4,802 & 3,562 & 2,015 \\
\hline $\begin{array}{l}\text { Balance End } \\
\text { Period }\end{array}$ & 673,267 & 627,042 & $\begin{array}{l}592,273 \\
\end{array}$ & 454,163 \\
\hline $\begin{array}{l}\text { All figures } \\
\text { are in }\end{array}$ & $\begin{array}{c}\text { Thousand } \\
\text { s }\end{array}$ & $\begin{array}{c}\text { Thousan } \\
\text { ds }\end{array}$ & $\begin{array}{c}\text { Thousan } \\
\text { ds }\end{array}$ & $\begin{array}{c}\text { Thousa } \\
\text { nds }\end{array}$ \\
\hline Currency & SAR & SAR & SAR & SAR \\
\hline
\end{tabular}

Table 2: Financial Performance of SADAFCO (Statement of Income)

\section{SADAFCO AND THE SAUDI BUSINESS ENVIRONMENT}

Conducting a business in any local environment needs cultural adherence in the given environment and Saudi business environment is not exception to this. SADAFCO adopting the Islamic concepts based on Shariah (Islamic jurisprudence). SADAFCO is taking the following steps for incorporating Islamic teachings to serve its' Muslim stakeholders in managing their organization.

Performing Solat on time: Five times prayers daily, is something a must since this is the second pillar of Islam and an obligatory religious duty for every Muslim. The primary purpose of performing prayers five times a day is to act as a person's communication with Almighty (Allah) and purification of the heart is the ultimate religious objective of Solat. SADAFCO pays great attention to Solat performance as this a ritual obligation of its entire workforce, first when the call of azan begins all works and meetings paused and resumes back when Solat time is over. SADAFCO provides prayer room to pray in a congregation. Also, SADAFCO provides sufficient time and places for their employees to perform their religious duties.

Halal products: SADAFCO is doing their business based on the concept of halal (permissible). Being a Muslim owned company and running the business strictly based on the halal concept, the knowledge about the issue of halal food is viewed seriously by customers as they are Muslims. SADAFCO is providing a halal product only is an assurance to the customers. It is an obligation or fardhu kifayah (individual obligations) to provide halal goods and services for consumption by the fellow Muslims to buy [3]. All the manufacturers and suppliers of SADAFCO have halal certificates, signed by competent authorities as a halal logo to be used, available on their website, as a way to inform and reassure that their products are halal and Shariah compliant.

Service to community: SADAFCO persists in its endeavors to serve the community in which it operates as a responsibility to community and this involvement takes many different forms. In Jeddah and Dammam, the Company has been involved as a strategic partner with MODON's 2017 School Visitation Program by hosting groups of school children to show them how products are manufactured right from the stage of procurement of raw materials. The Company contributed products to charities and schools catering to special needs. SADAFCO also contributed products to Quran schools. SADAFCO supported schools with healthy breakfast initiatives during the year, including on the 'International Milk Day'. The Company supported Ministry of Health vaccination programs. All these initiatives come from the responsibility to community as its commitments to CSR, which is encouraged by Islamic teachings.

Al-Musawarah (Equality): SADAFCO applies the principle of equality among employees in the organization. The management gives incentives to all the employees who excel without discrimination and without favoritism. Benefits on a 
par or better than similar companies are offered to ensure that employees are happy and sufficiently rewarded for their contributions. Equality is achieved when recognizing the rights of all members of society, thus SADAFCO has provided equal opportunities for groups such as women and people with disabilities to work there.

Does the company and its' management encourage its employees to incorporate these Islamic concepts into management practices and how is it done is a challenge emerging from the local environment. SADAFCO rises to the challenge and shows a great passion to Islamic concepts and motivates its employees to implement them efficiently into management practices. Some Islamic concepts' implementations by SADAFCO are as follows:

- Niyyah (intention): For every human act there should be clear intentions in Islam since it matters the most. The implications of this principle in SADAFCO are that employees are not punished for making unintended mistakes, but are rewarded rather punished for their intended goals, ideas, plans, and strategies rather than just the results of their actions that may be influenced by factors outside their control.

- Taqwa (God consciousness): Taqwa is simply defined as God fearing but this term has a range of meanings. This refers to righteousness, piety, so the person must be in a state of mindfulness and fear of Allah (SWT). When someone filled with the spirit of Taqwa, a person will refrain from behaving unjustly and will command his/her soul to move from the state of ammara (wrong temptations) to a higher spiritual level of lawama (positive temptations). Henceforth any criticism and advice extended to improve oneself become a common practice and even a moral obligation, when wrong doings are seen or observed by people engaged in SADAFCO becomes a work culture.

- Ihsan (love for God): This concept explained by the Prophet Mohammad (PBUH) as meaning "that you worship Allah as if you see Him, for even if you do not see Him, He sees you", it implies that makes the person behaving at his/her best without the need for any human supervision. In this context, SADAFCO's employees try to not shrinking works even when their bosses are not around.

- Sabar (patience): The Holy Quran specifically indicates patience as one of the desirable virtues and is the highest level of Iman (faith). In SADAFCO, employees trying to be patient when they work under pressure. Also, managers being patient in making decisions to reduce the possibility of making committing mistakes under undue pressure.

- Adl (justice): Justice is the cornerstone of the Islamic value system; an Islamic perspective of management system cannot hold water without Justice. It is to protect people's freedom and equality. All people are equal what truly counts is their actions and deeds. In SADAFCO where justice prevails, employees are treated and rewarded fairly. Managers treat their employees with respect and courtesy, and never look down to them or ignore their views and suggestions out of arrogance status and hierarchy.

- Ikhlas (sincerity): The concept of sincerity is the foundation upon which individual actions should be built, and, further, from which Allah (swt) will pass judgment on those actions. On this basis, any activity which does not have sincerity as its core value will not contribute to the good deeds which will be rewarded in the hereafter (Akhirah). Work is worship or in different term is a form of ibaadah and in serving the organization well, one serves Allah (al-Quran 39:14). In this context, employees practicing the concept of sincerity in SADAFCO by considering work as worship.

- Amanah (trust): a duty or obligation which an individual is tasked with and therefore obliged to fulfil, thus oblige Muslims to be trustworthy. SADAFCO gives trust to those who work in it, which leads to consultation and delegation of authority to employees.

- Itqan (Conscientious of self-improvement): A qualityrelated term used to denote continually improving performance in any task or function. It sounds like the Japanese concept of Kaizen managing quality of organizational life. In SADAFCO, employees, also managers work hard and strive to improve the quality of products and services through the promotion of continuous learning, training and innovation.

\section{‡ 3. MANAGEMENT STYLE OF SADAFCO}

Corporate leadership of any company plays a significant role by the organization managers. Conversant with the ideas of servant-leadership and guardian-leadership concepts SADAFCO management did not shun responsibility as servant first and leader afterwards. The question is how do they put these ideas into practice? The company uses the technique of Shura (collective decision making)?

Since a leadership within organization is crucial, it is the ability to show the way and to guide, direct or influence the actions of others. According to Islam, the two main roles of a leader are those of servant leader and guardian leader. First, the leader is the servant of his followers, who guides them towards good work ethics and practice. The second role is to protect his/her community against tyranny and oppression, to encourage God consciousness, and to promote justice. The managers of SADAFCO are conversant with the ideas of servant leadership and guardian leadership and consider them as the main source to guaranteeing highly God consciousness and qualitative leadership. This appears in several practices, SADAFCO's leaders have motivation to actively listening to its employees and support them in determining decisions, and they treat employees with respect and appreciation and strived 
to understand them. Also, they strive to build a harmonious working environment in the organization and trust among employees because they believe that mutual commitment and community work accomplishes the goals. Shura is the right way to make the best decision on worldly matters, in the absence of a prescribed organizational policies enhancing participation in discussions and making suggestions are key leadership attributes in Islam. It is required from Muslim leaders and SADAFCO using Shura for all departments before making decisions.

Islamic management means undertaking human activities as per the guidance of Allah (swt) and following his apostle (saw) with a particular mindset enshrined in ones' integrity and skills to achieve certain objectives of life. The company reported two Islamic management methods. First, principle is Cooperation the company encourages its employees to cooperate with each other through joint work. Secondly, Solidarity, this great method is assured a lot in Islam and at all levels. It is considered as a measure of SADAFCO's ability to pursue shared objectives quickly and effectively through mutual cooperation and support in the organization.

\section{SPIRITUALITY ENCOMPASSING PERFORMANCE MANAGEMENT}

Islam created a unique management paradigm that nurtured civility, prosperity, diversity and happiness among people of different creeds and ethnic origins around the globe for more than 1000 years [4]. When it comes to Islam there is no separation between worldly or mundane activities and religious aspects of life. Most of the employees working in SADAFCO are Muslims, as the religious impression is dominated in most of companies in Saudi Arabia. Some respondents reported that being Muslims, they follow the teachings of Islamic Sharia such as honesty and trustworthiness. This makes them work more efficiently because their religion orders them to do good and sincerity in work. Other respondents emphasized the importance of spiritual aspect, and that doing worship such as praying on time contributes to improve their efficiency in the workplace.

Given the above value based management of SADAFCO, there still exists challenges especially the pandemic brought by Covid-2019 on financial health of the company. The big blow to the economic well-being of the countries including developed nations was a matter of concern. Saudi Arabia being member of the OPEC nations highly depends upon the export of oil and gas to generate commercial activities. Once the engine of economic growth suffered a setback due to contraction of demand in the energy sector has devastating effect in the entire sectors including retail industry since purchasing power of the market take a seat. SADAFCO is no exception to this. The author still has to wait and see the financial report and data to assess the impact and the challenges faced by the company due to financial indicator for the year 2020 .

\section{EPILOGUE}

The religious impression is dominated in most of companies in Saudi Arabia, which considers the Islam as the main source of legalizing constitution in different aspects of individual and organizational lives according to Sharia principles as highlighted and conformed by Islamic management experts [5]. As an organization that follows Islamic teachings, SADAFCO provided special facilities for Muslims. These facilities include prayer room (Musalla) to pray in a congregation, this prayer room is large and clean and also fully equipped with facilities to provide comfort to all managers and employees who stood before God to show solidarity and equality before Him. Also, SADAFCO provides sufficient places for their employees to perform their religious duties. During the month of Ramadan timings were shortened a bit to lessen the burden of work. For Hajj, the management helps the employees to do the duty of performing Hajj by giving them a paid vacation to do Hajj by taking turn.

\section{QUESTIONS}

Q1: Why SADAFCO not trying to enter new markets outside the Middle East since it is leading and has a successful experience in the given environment?

Q2: How the non-Muslim employees view the Islamic Management System in SADAFCO?

Q3: Islamic motivation theories based on spirituality work in a given environment, how does SADAFCO deal with those who do not subscribe to Islamic teachings?

Q4: Calculate financial ratios of SADAFCO and suggest ways and means to double the financial performance of the company in next five years.

\section{REFERENCES}

[1] Sadafco. (2020). Our History.

[2] tadawul. (2020). Saudia Dairy and Foodstuff Co.

[3] Alfalih, A. (2016). Religion, culture and management: a comparative study of the impact of Islam and Saudi culture on HRM practices of indigenous and foreign owned and managed corporations in Saudi Arabia.

[4] Mushtaq, M., Saghir, A. R., \& Kayani, M. M. (2014). Islamic Management System and its Application in the 21st Century World. International Journal of Academic Research in Economics and Management Sciences, 3(3), 92.

[5] Abbasi, A. S., Rehman, K. U., \& Bibi, A. (2010). Islamic management model. African Journal of Business Management, $4(9), 1873-1882$

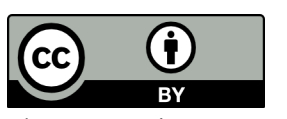

(C) 2020 by the Dr. Zaid Ahmad Ansari. Submitted for possible open access publication under the terms and conditions of the Creative Commons Attribution (CC BY) license (http://creativecommons.org/licenses/by/4.0/). 